\title{
Front Matter: Volume 8386
}

, "Front Matter: Volume 8386," Proc. SPIE 8386, Full Motion Video (FMV) Workflows and Technologies for Intelligence, Surveillance, and Reconnaissance (ISR) and Situational Awareness, 838601 (7 June 2012); doi: 10.1117/12.979144

SPIE Event: SPIE Defense, Security, and Sensing, 2012, Baltimore, Maryland, United States 


\title{
PROCEEDINGS OF SPIE
}

\section{Full Motion Video (FMV) Workflows and Technologies for Intelligence, Surveillance, and Reconnaissance (ISR) and Situational Awareness}

\author{
Donnie Self \\ Editor
}

23-24 April 2012

Baltimore, Maryland, United States

Sponsored and Published by

SPIE

Volume 8386 
The papers included in this volume were part of the technical conference cited on the cover and title page. Papers were selected and subject to review by the editors and conference program committee. Some conference presentations may not be available for publication. The papers published in these proceedings reflect the work and thoughts of the authors and are published herein as submitted. The publisher is not responsible for the validity of the information or for any outcomes resulting from reliance thereon.

Please use the following format to cite material from this book:

Author(s), "Title of Paper," in Full Motion Video (FMV) Workflows and Technologies for Intelligence, Surveillance, and Reconnaissance (ISR) and Situational Awareness, edited by Donnie Self, Proceedings of SPIE Vol. 8386 (SPIE, Bellingham, WA, 2012) Article CID Number.

ISSN 0277-786X

ISBN 9780819490643

Published by

SPIE

P.O. Box 10, Bellingham, Washington 98227-0010 USA

Telephone +1 3606763290 (Pacific Time) · Fax +1 3606471445

SPIE.org

Copyright (C) 2012, Society of Photo-Optical Instrumentation Engineers

Copying of material in this book for internal or personal use, or for the internal or personal use of specific clients, beyond the fair use provisions granted by the U.S. Copyright Law is authorized by SPIE subject to payment of copying fees. The Transactional Reporting Service base fee for this volume is $\$ 18.00$ per article (or portion thereof), which should be paid directly to the Copyright Clearance Center (CCC), 222 Rosewood Drive, Danvers, MA 01923. Payment may also be made electronically through CCC Online at copyright.com. Other copying for republication, resale, advertising or promotion, or any form of systematic or multiple reproduction of any material in this book is prohibited except with permission in writing from the publisher. The CCC fee code is 0277-786X/12/\$18.00.

Printed in the United States of America.

Publication of record for individual papers is online in the SPIE Digital Library.

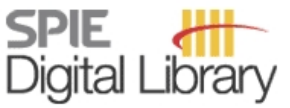

SPIEDigitalLibrary.org

Paper Numbering: Proceedings of SPIE follow an e-First publication model, with papers published first online and then in print and on CD-ROM. Papers are published as they are submitted and meet publication criteria. A unique, consistent, permanent citation identifier (CID) number is assigned to each article at the time of the first publication. Utilization of CIDs allows articles to be fully citable as soon as they are published online, and connects the same identifier to all online, print, and electronic versions of the publication. SPIE uses a six-digit CID article numbering system in which:

- The first four digits correspond to the SPIE volume number.

- The last two digits indicate publication order within the volume using a Base 36 numbering system employing both numerals and letters. These two-number sets start with $00,01,02,03,04$, $05,06,07,08,09,0 A, 0 B \ldots 0 Z$, followed by 10-1Z, 20-2Z, etc.

The CID number appears on each page of the manuscript. The complete citation is used on the first page, and an abbreviated version on subsequent pages. Numbers in the index correspond to the last two digits of the six-digit CID number. 


\section{Contents}

$\checkmark$ Conference Committee

\section{THE FUTURE: CONVERGING MOTION IMAGERY AND INTELLIGENCE}

838603 Transformational motion imagery processing, exploitation, and dissemination (PED) technologies [8386-02]

G. S. Creech, National Geospatial-Intelligence Agency (United States); M. Brennan, Moriarty and Associates (United States)

838604 Convergence in full motion video processing, exploitation, and dissemination and activity based intelligence [8386-03]

M. Phipps, G. Lewis, General Dynamics Advanced Information Systems (United States)

\section{CHALLENGES AND SOLUTIONS WITH MOTION IMAGERY}

838605 Improving usability for video analysis using gaze-based interaction [8386-04]

J. Hild, E. Peinsipp-Byma, E. Klaus, Fraunhofer Institute of Optronics, System Technologies and Image Exploitation (Germany)

838606 Georegistration of motion imagery with error propagation [8386-05]

M. D. Pritt, K. J. LaTourette, Lockheed Martin Information Systems and Global Services

(United States)

838607 Full-motion video georegistration for accuracy improvement, accuracy assessment, and robustness [8386-06]

C. R. Taylor, R. J. Settergren, BAE Systems (United States)

838608 Dealing with the data deluge: file systems and storage technologies [8386-07]

D. H. Denson, NetApp U.S. Public Sector (United States)

THE CLOUD AND MOTION IMAGERY PLUS VIDEO TEST DATA

838609 Motion/imagery secure cloud enterprise architecture analysis [8386-08]

J. L. DeLay, Harris Corp. (United States)

8386 OA Transitioning ISR architecture into the cloud [8386-09]

T. D. Lash, SAIC (United States)

\section{ACTIVITY-BASED INTELLIGENCE I}

8386 OD Activity-based exploitation of Full Motion Video (FMV) [8386-12]

S. Kant, Cognika Corp. (United States) 
$8386 \mathrm{OE} \quad$ Automated motion imagery exploitation for surveillance and reconnaissance [8386-13] S. Se, F. Laliberte, V. Kotamraju, M. Dutkiewicz, MacDonald, Dettwiler and Associates Ltd. (Canada)

8386 OF Unsupervised visual landmark extraction for place recognition [8386-14] E. Sariyanidi, H. Temeltaş, Istanbul Technical Univ. (Turkey)

8386 OG Placement of Full Motion Video (FMV) frames in geographic context using pursuer [8386-15] C. N. Taylor, D. Uppenkamp, Air Force Research Lab. (United States); K. Shannon, Intelligent Software Solutions (United States)

\section{ACTIVITY-BASED INTELLIGENCE II}

$8386 \mathrm{OH} \quad$ Automated FMV SMART camera using dynamically updated LUTs [8386-16]

$\mathrm{H}$. Jaenisch, The Johns Hopkins Univ. (United States) and Licht Strahl Engineering Inc. (United States); J. Handley, Licht Strahl Engineering Inc. (United States)

8386 Ol Real-time anomaly detection in full motion video [8386-17]

G. Konowicz, J. Li, Old Dominion Univ. (United States)

8386 OJ Emerging standards suite for wide-area ISR [8386-18] P. F. Maenner, Motion Imagery Standards Board (United States)

8386 OK Increased ISR operator capability utilizing a centralized 360 degree full motion video display [8386-19]

K. Andryc, J. Chamberlain, T. Eagleson, G. Gottschalk, B. Kowal, P. Kuzdeba, D. LaValley, E. Myers, S. Quinn, M. Rose, B. Rusiecki, L-3 KEO (United States)

\section{PANEL DISCUSSION ON STANDARDS: THE FOUNDATION OF THE FUTURE}

$83860 \mathrm{M}$ OGC observations and measurements standard to support feature-based motion imagery tracking [8386-21]

L. S. Randall, H. J. Antonisse, Motion Imagery Standards Board (United States)

8386 ON Image-based tracking: a new emerging standard [8386-22]

J. Antonisse, S. Randall, Motion Imagery Standards Board (United States)

\section{TACTICAL AND WIRELESS DISSEMINATION}

838600 The evolution of wireless video transmission technology for surveillance missions [8386-23] C. M. Durso, E. McCulley, Vislink Surveillance (United States)

8386 OP Salience-based compression: providing FMV over low-bit rate channels [8386-24]

M. A. Isnardi, A. Kopansky, S. Chai, SRI International Sarnoff (United States)

Author Index 


\title{
Conference Committee
}

\author{
Symposium Chair
}

Kevin P. Meiners, Office of the Secretary of Defense (United States)

Symposium Cochair

Kenneth R. Israel, Lockheed Martin Corporation (United States)

Conference Chair

Donnie Self, National Geospatial-Intelligence Agency (United States)

Program Committee

Mark A. Aitken, Sinclair Broadcast Group, Inc. (United States)

Lawrence Brody, Communications Engineering, Inc. (United States)

John Marino, National Association of Broadcasters (United States)

Gary Nadler, Consultant, Commercial Broadcast Industry (United States)

James Snyder, U.S. Library of Congress (United States)

Norman S. Stein, TASC, Inc. (United States)

Peter Symes, Society of Motion Picture and Television Engineers (United States)

Kevin L. West, Office of the Under Secretary of Defense for Intelligence (United States)

\section{Session Chairs}

The Future: Converging Motion Imagery and Intelligence

Gregory S. Creech, National Geospatial-Intelligence Agency (United States)

Challenges and Solutions with Motion Imagery

Gary Nadler, Consultant, Commercial Broadcast Industry (United States)

The Cloud and Motion Imagery Plus Video Test Data

Randy L. Richard, Defense Information Systems Agency (United States)

Activity-Based Intelligence I

Gregory S. Creech, National Geospatial-Intelligence Agency (United States) 
Activity-Based Intelligence II

Gary Nadler, Consultant, Commercial Broadcast Industry (United States)

Tactical and Wireless Dissemination

Gary Nadler, Consultant, Commercial Broadcast Industry (United States)

Panel Discussion: Standards-The Foundation of the Future Donnie Self, Moderator, National Geospatial-Intelligence Agency (United States)

Randy L. Richard, Defense Information Systems Agency (United States)

Jim Antonisse, Booz Allen Hamilton Inc. (United States)

Scott Randall, Booz Allen Hamilton Inc. (United States) 